\title{
The Anatomy of the Oesophagus, Stomach and Intestine in Common Wolffish (Anarhichas lupus L.): A Basis for Diagnostic Work and Research
}

\author{
By H. Hellberg and I. Bjerkås
}

Department of Morphology, Genetics and Aquatic biology, Norwegian College of Veterinary Medicine, Oslo, Norway.

\begin{abstract}
Hellberg $\mathbf{H}$, Bjerkås I: The anatomy of the oesophagus, stomach and intestine in common wolffish (Anarhichas lupus $\mathbf{L}$.). Acta vet. scand. 2000, 41, 283-297. - The alimentary canal of laboratory-reared common wolffish (Anarhichas lupus L.) was studied using light and electron microscopy. In the oesophagus, a simple columnar microvillous epithelium with transport characteristics was observed in addition to the main striated squamous epithelium. An osmoregulatory function is proposed for the simple columnar epithelium, which was supported by wide, thin-walled vessels. In the stomach, a separate type of neck cells was observed leading into the acinar gastric glands, which morphologically consist of one cell type: chief cells. The intestine was divided into a proximal and distal segment by an intestinal valve. Pyloric caeca were not present. We propose that shallow, crypt-like structures in the intestinal mucosa are the sites of epithelial-cell proliferation in juveniles and adults. The length of microvilli decreased from approximately $4 \mu \mathrm{m}$ in the cranial part of the proximal intestine, to $1.5 \mu \mathrm{m}$ in the distal intestine. In the distal intestine, rod-shaped bacteria were observed between microvilli. An extensive system of thin-walled vessels was observed in the submucosa of juvenile and adult wolffish stomach and intestine. Eosinophilic granular cells were numerous in the perivascular connective tissue in the gastric and intestinal submucosa of adults and juveniles, but were not observed in larvae.
\end{abstract}

Teleostei; histology; ultrastructure; fish anatomy.

\section{Introduction}

The common wolffish (Anarhichas lupus L.) and the spotted wolffish (Anarhichas minor Olafsen) are considered promising species for cold-water marine fish farming (Moksness 1994), and the entire reproductive cycle may now be completed under laboratory conditions (Pavlov \& Novikov 1986, Pavlov \& Moksness 1994 A). Wolffish eggs are large, $4.0-6.3 \mathrm{~mm}$ in diameter, and newly hatched larvae are 19-22 $\mathrm{mm}$ long (Jonsson 1982, Pavlov \& Novikov 1986). The size at hatching is comparable to that of Atlantic salmon (Salmo salar L.), but wolffish hatch at a later stage of development (1050 day-degrees) and may start feeding im- mediately (Pavlov \& Moksness 1994 B). Wolffish larvae are pelagic, and do not metamorphose before settling at the bottom; fish $>50$ $\mathrm{mm}$ are usually categorized as juveniles (Moksness et al. 1989). After the first year, wolffish are usually classified as adults and characterized by year class and sexual maturity. Knowledge of the normal anatomy of the alimentary canal is essential for evaluation of pathological changes and possible negative effects of diets and feeding regimes (Baeverfjord \& Krogdahl 1996). In the wild, wolffish are carnivores that feed mainly on shellfish and echinoderms (Jonsson 1982). Available material on 
the anatomy of the alimentary canal of common wolffish is limited (Haus 1897, Verighina 1974, Bray 1987), and to the present authors' knowledge, no studies of the juvenile stage or the ultrastructure of the alimentary canal have been published.

The aim of the present study was to provide a better knowledge of the anatomy of the alimentary canal in common wolffish at different developmental stages as a basis for diagnostic work and research. This article presents morphological findings in the oesophagus, stomach and intestine of laboratory-reared common wolffish.

\section{Materials and methods}

\section{Sampling procedure}

The material comprised larvae, juveniles and adults of common wolffish. Larvae and juveniles were incubated, hatched and reared at the Institute of Marine Research, Flødevigen Marine Research Station (Pavlov \& Moksness 1994 B). Adults were laboratory-reared from wild-caught larvae or incubated, hatched and reared under laboratory conditions. The fish were fed commercial dry pellets, Elite Plus ${ }^{\circledR}$ (T. Skretting A/S, Norway).

Fifteen 1-day-old larvae (Table 1) were selected at random from a population of approximately 800 larvae hatched 21 st of April 1994. Mean incubating temperature was $7^{\circ} \mathrm{C} \pm 0.2$. The larvae were killed by decapitation and fixed in $10 \%$ buffered formalin. A transverse section of the trunk, including the abdominal cavity, was sampled for light microscopy.

Twenty 6-month-old juveniles (Table I) were sampled 4th of November 1993. The water temperature ranged from 7 to $12^{\circ} \mathrm{C}$ during the rearing period. The fish were killed with an overdose of chlorobuthanol and the abdominal cavity opened. The entire alimentary tract was removed, fixed in $10 \%$ buffered formalin $(\mathrm{n}=$ $10)$, Bouins solution $(n=5)$ or chilled $3 \%$ glu-
Table 1. Weight and length of wolffish larvae and juveniles.

\begin{tabular}{lcc}
\hline Age group & $\begin{array}{c}\text { Mean weight } \\
\text { (range) } \\
\text { Standard dev. }\end{array}$ & $\begin{array}{c}\text { Mean length } \\
\text { (range) } \\
\text { Standard dev. }\end{array}$ \\
\hline Larvae & 0,073 gr. $^{*}$ & $\begin{array}{c}2,18 \mathrm{~cm} \\
(2,0-2,3) \\
\mathrm{n}=15\end{array}$ \\
\hline Juvenile & 10,16 gr. & $9,63 \mathrm{~cm}$ \\
$\mathrm{n}=20$ & $(5,8-14,8)$ & $(8,5-11,5)$ \\
& 2,79 & 0,915 \\
\hline
\end{tabular}

* Due to the low weight of the larvae, they were weighed as a group, and mean weight calculated.

taraldehyde in $0,1 \mathrm{M}$ cacodylate buffer, $\mathrm{pH} 7.2$ $(n=5)$. The fixed material was sampled for light-microscopy at 6 points (Fig. 1).

Seven adult wolffish, measuring from 25 to 40 $\mathrm{cm}$, were included in the study. The fish were killed with an overdose of chlorobuthanol and the abdominal cavity opened. The alimentary tract was sampled at 6 points (Fig. 1), and samples fixed in $10 \%$ buffered formalin and Bouins solution. In 5 adults, samples were also fixed in glutaraldehyde.

\section{Light microscopy}

Samples were dehydrated in ethanol, embedded in paraffin and sectioned at a Reichert-Jung Hn

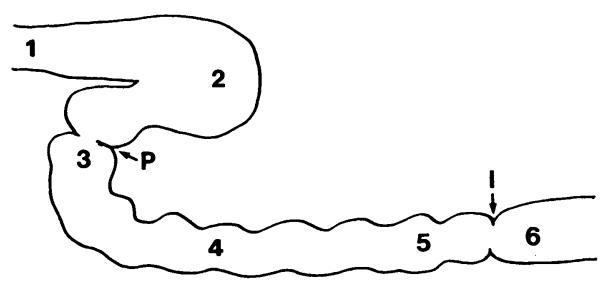

Figure 1. Schematic drawing of alimentary canal with sample-points 1-6. The posterior, intra-abdominal part of the oesophagus (1) was sampled, along with stomach (2), cranial (3), middle (4) and caudal part of proximal intestine (5) and distal intestine (6). Pyloric sphincter (P) and intestinal valve (I). 


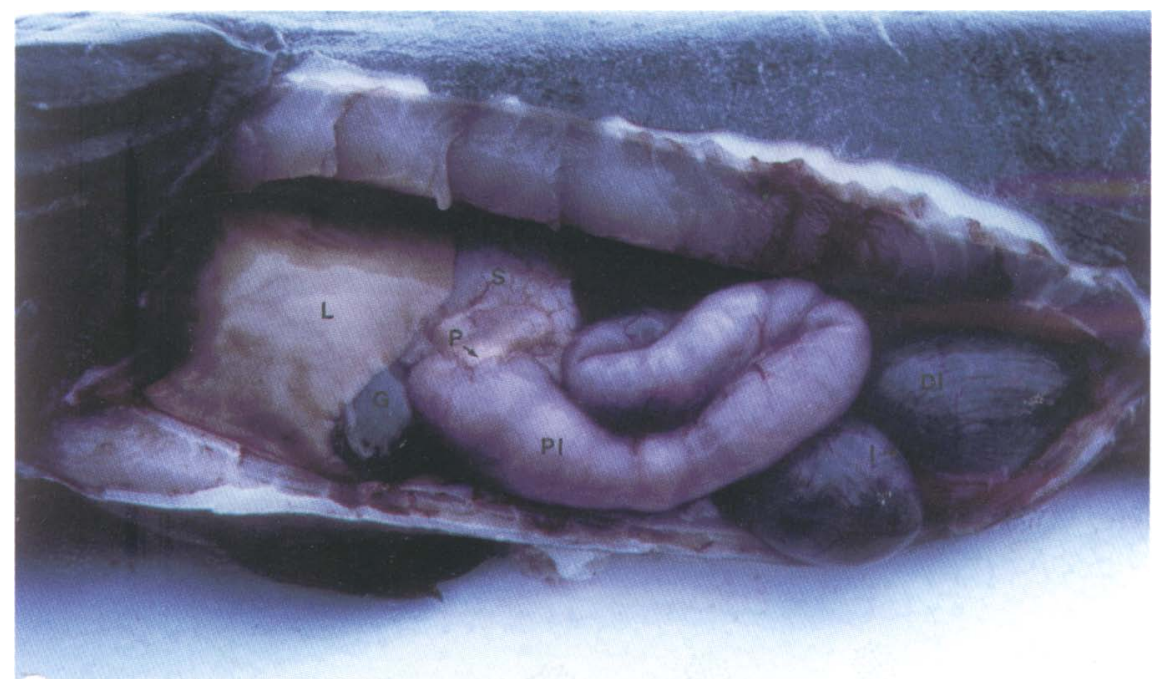

Figure 2. Organs in situ, adult wolffish: The left abdominal wall has been removed. The liver (L) covers the cranial part of the stomach $(\mathrm{S})$. The large gallbladder $(\mathrm{G})$ is seen at the ventral edge of the liver. The pylorus is distinct (P). The proximal intestine (PI) is coiled in a sigmoidal shape in the abdominal cavity. The transition between proximal and distal intestine (DI) is marked (I).

40 microtome. Transverse and some longitudinal sections (3-5 $\mu \mathrm{m})$ were mounted on glass slides and stained with haematoxylin-eosin (HE), periodic acid-Schiff (PAS) and Van Gieson (VG). Selected sections were stained with Alcian Blue PAS and modified Martius-ScarletBlue (MSB) (Carleton \& Leach 1968). Photomicrographs were taken with a Leitz Aristoplan microscope fitted with a Leica Wild MPS52 Photoautomat.

\section{Transmission-electron microscopy}

Oesophagus, stomach, cranial and middle proximal intestine and distal intestine were sampled from glutaraldehyde-fixed material (Fig. 1). Samples were postfixed in $2 \% \mathrm{OsO}_{4}$ in $0.1 \mathrm{M}$ cacodylate buffer, $\mathrm{pH} 7.2$ for 2 hours, dehydrated in ascending concentrations of ethanol and embedded in LX 112 Resin (Ladd Research Industries Inc., Burlington, Vermont). Semi-thin $(1 \mu \mathrm{m})$ sections were mounted on glass slides and stained with toluidine blue. Ultra-thin sections were mounted on copper grids, stained with uranyl acetate and lead citrate, and examined in a Jeol $100 \mathrm{~S}$ and a Philips 208S electron microscope.

\section{Results}

\section{Gross anatomy}

In the one-day-old larvae, the gastrointestinal tract was a short, straight tube, which could easily be divided into oesophagus, stomach, and proximal and distal intestine. Yolk sack remnants were found intraabdominally, attached to the liver.

In the juveniles and adults, the alimentary canal was relatively longer, but did not exceed total body length. The transition from oesophagus to stomach was not marked and there was no observable cardiac sphincter (Fig. 1). The stomach widened caudally and turned cranioventrally, creating a pouch. The ascending branch 


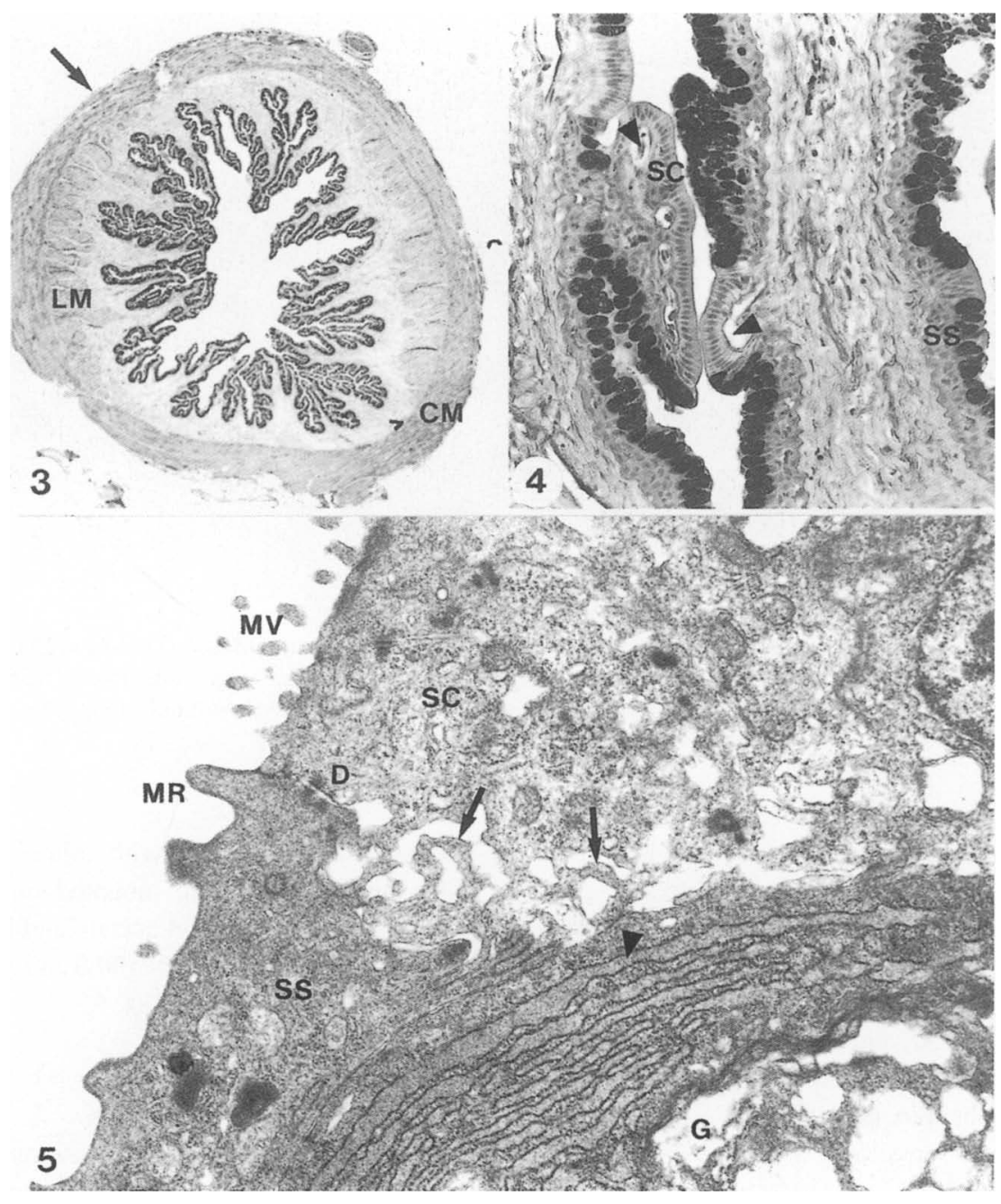

Figure 3. Light micrograph of HE stained transverse section of juvenile oesophagus, showing the extensive folding of the mucosa. The longitudinal primary folds incorporate mucosa, submucosa and occasional bundles of the inner longitudinal layer of striated muscle (LM). The circular outer layer of striated muscle (CM) and serosa (arrow) are also seen. $\times 23$.

Figure 4. Light micrograph of PAS stained adult oesophagus, showing stratified, squamous epithelium with PAS-positive mucous cells (SS) and PAS-negative simple columnar epithelium (SC). Wide capillaries (arrowheads) are seen in the lamina propria beneath the columnar epithelium. $\times 229$.

Figure 5. Ultramicrograph of oesophagus showing stratified (SS) and simple columnar (SC) epithelium. Peripheral rough endoplasmic reticulum (arrowhead) is seen in a goblet cell $(\mathrm{G})$ in the stratified squamous epithelium. Plasma membrane pleats (arrows). Microvilli (MV). Microridges (MR). Desmosome (D). $\times 16000$. 

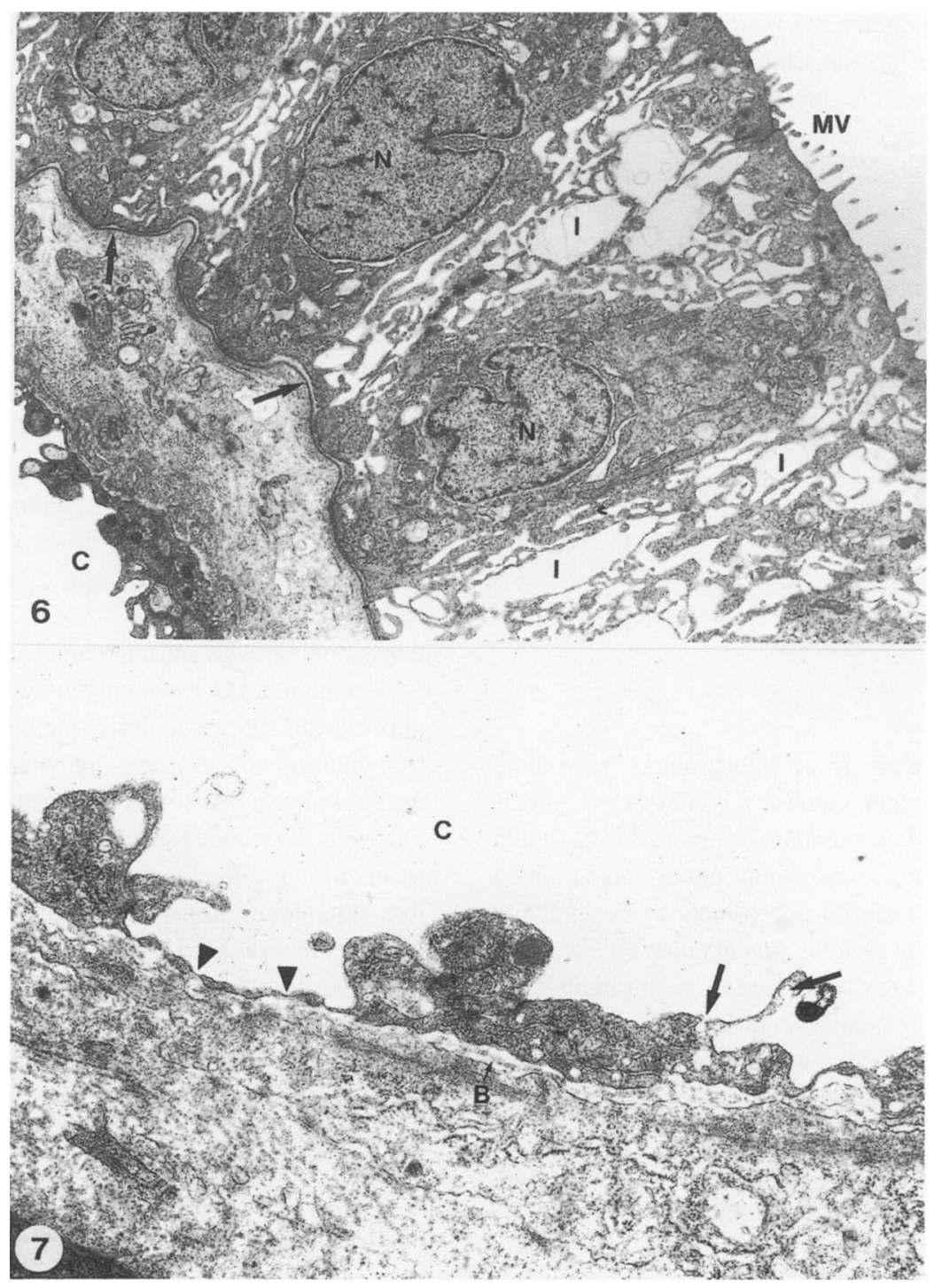

Figure 6. Ultramicrograph of oesophagus showing simple columnar epithelium and capillary (C) in the lamina propria. Extensive plasma membrane projections are seen laterally, reaching into dilated intercellular spaces (I). Nucleus (N). Microvilli (MV). The simple columnar epithelium has a well-developed basal lamina (arrows). $\times 6000$.

Figure 7. Ultramicrograph of oesophagus showing the endothelium of a capillary associated with the simple columnar epithelium. The endothelial cells are filled with cytoplasmic vesicles, some of which (arrows) open into the capillary lumen (C). Fenestrae-like structures (arrowheads). Note the poorly developed basal lamina (B). $\times 20000$. 
narrowed slightly and there was a marked constriction at the transition from the stomach to the intestine. The intestine continued cranially only for a short distance, and then turned caudoventrally (Fig. 2). There were no discernable pyloric caeca. The intestine was suspended in a long dorsal mesentery, and the transition from proximal to distal intestine was marked by a distinct constriction, with a transverse circular luminal valve or ridge. The distal intestine, which was short and generally had a larger diameter than the proximal, continued caudally to the anal opening. The luminal surface of the intestine displayed prominent longitudinal folds, which increased considerably from the juvenile to the adult stage. Close inspection of the velvety mucosal surface revealed smaller, secondary folds.

\section{Microscopy}

Oesophagus. In all age groups, the wall of the oesophagus consisted of the layers generally found in the gut: 1) tunica mucosa, 2) tela submucosa, 3) tunica muscularis and 4) tunica adventitia rostrally and tunica serosa caudally (Fig. 3). The mucosa was extensively folded in the juvenile and adult stages, with longitudinal primary folds, and secondary and even tertiary mucosal folds or rugae. Glandular structures were not observed. In one-day-old larvae, mostly primary folds were seen.

All age groups exhibited 2 distinctly different types of oesophageal epithelium. The main type was a stratified, squamous epithelium with numerous PAS-positive mucous cells (Fig. 4). The second type, a simple columnar epithelium, was most frequently found at the tip of the mucosal folds. In juveniles and adults, the 2 types of epithelium alternated in a relatively regular fashion, while in the larvae the simple columnar epithelium dominated in the caudal oesophagus.

Ultrastructurally, the squamous epithelium was rich in tonofilaments and exhibited microridges on the luminal surface (Fig. 5). The columnar cells were characterized by short microvilli at their luminal surface, and extensive pleating of the plasma membrane laterally and basally (Figs. 5 and 6). Transitional cells were not observed.

In the lamina propria wide capillaries were seen in close proximity to the simple columnar epithelium, while vascular elements were less prominent in connection with the stratified, squamous type (Fig. 4). Ultrastructurally, the endothelium of these vessels had luminal cytoplasmic projections, and was extremely attenuated in places, $0.05-0.1 \mu \mathrm{m}$ thick, with an incomplete basal lamina and fenestrae-like structures (Figs. 6 and 7).

Occasional smooth muscle cells were detected in the subepithelial connective tissue, but an organized, distinct muscularis mucosae was not seen, making an exact division between propria and submucosa difficult. The tunica muscularis consisted of striated muscle fibres organized in an inner longitudinal and an outer circular layer. The inner longitudinal layer was not continuous, but consisted of more or less separate bundles (Fig. 3), and was not prominent in the larvae. The outer circular layer was continuous, and in histological sections represented $1 / 2$ $1 / 3$ of the total wall thickness in the juveniles, but was only 2-4 cell-layers thick in the larvae.

Stomach. In all age groups the transition between oesophageal and gastric epithelium was sharply defined. The epithelial layer was differentiated into a microvillous superficial part, with prominent gastric pits (foveolae gastricae), and a glandular part (Figs. 8 and 9). Acinar gastric glands were present throughout the entire stomach, although less numerous in the distal or pyloric part, particularly in the larvae. The surface epithelium of the stomach lacked 


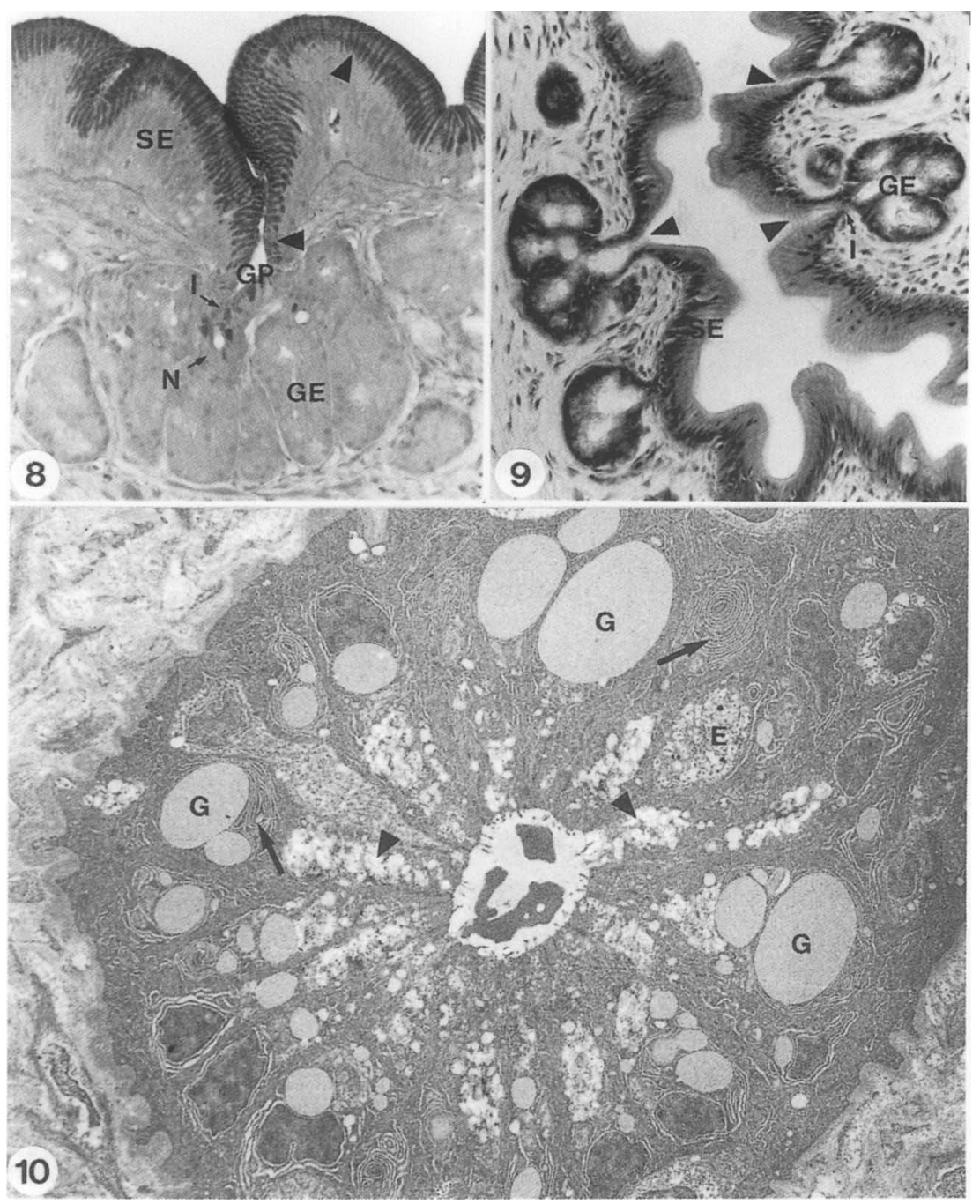

Figure 8. Light micrograph of PAS stained adult stomach. Superficial epithelium (SE) with PAS-positive granules (arrowheads) in the apical cytoplasm. Gastric pit (GP). Isthmus (I). The neck portion (N) is very short. The glandular epithelium (GE) is PAS-negative. $\times 229$.

Figure 9. Light micrograph of HE stained juvenile stomach, showing surface epithelium (SE), gastric pit (arrowheads) and acinar glands (GE). Acinar glands, in groups of 2-4, empty into gastric pits via a common duct or isthmus (I). x 229.

Figure 10. Ultramicrograph of adult stomach showing distal isthmus. Microvillous superficial epithelial cells containing mucous granules (arrowheads). The isthmus part also contains large, electron-lucent granules (G) and extensive endoplasmic reticulum (arrows) of the same type as seen in the neck cells. Endocrine cell $(E) . \times 3600$. 
goblet cells, and the apical cytoplasm contained PAS-positive mucous granules (Fig. 8). Occasional endocrine cells (enteroendocrine cells) were observed in the epithelial layer (Fig. 10). The height of the epithelial cells and the amount of PAS-positive material in the apical cytoplasm decreased gradually from the luminal surface to the bottom of the gastric pits, and further into a narrow tubular part, or isthmus. Glandular acini emptied into the isthmus via short neck portions, formed by cells almost devoid of microvilli, and with numerous large, cytoplasmic, membrane-bound droplets containing a moderately PAS-positive, AB-negative, electron-lucent homogeneous material. These droplets were most easily distinguished in the adults (Fig 10). Varying numbers of droplets were also seen in some isthmus cells, in addition to the PAS-positive mucous granules. The glandular cells were of one morphological type, with basal nuclei and spherical, electron-dense zymogen granules, $1.5-2.5 \mu \mathrm{m}$ in diameter, in the apical cytoplasm.

The submucosa of both the juvenile and adult stomach had a layer of dense collagen-rich connective tissue immediately adjacent to the muscularis. This layer, which was much less distinct than the stratum compactum in salmonids, contained wide, extremely thin-walled, irregularly shaped vessels that to various degrees surrounded arteries and veins. These vessels usually did not contain erythrocytes, and their walls were composed of little more than a thin layer of endothelium, less than $0.2 \mu \mathrm{m}$ at the most attenuated. A basal lamina was incomplete or lacking. These features were most pronounced in the adults, but were also seen in the juveniles. In the larvae, connective tissue and vascular elements were less prominent. In both juveniles and adults, eosinophilic granular cells (EGCs) were observed in the collagen-rich part of the gastric submucosa, particularly surrounding larger vessels, and also perivascularly in the subserosal and mesenterial connective tissue. Definite EGCs were not observed in one-day-old larvae.

The tunica muscularis of the stomach consisted of an inner circular and outer longitudinal layer of smooth muscle fibres. The inner circular layer was continuous with the outer longitudinal layer of the oesophagus, but the striated muscle fibres of the oesophagus were gradually replaced by smooth muscle fibres in the cranial part of the stomach. The inner longitudinal layer of the oesophagus became attenuated distally, and did not continue into the stomach.

Intestine. In adults and juveniles, the intestinal mucosa was extensively folded, with tall, longitudinal primary folds formed by the mucosa and submucosa, and a large number of secondary folds involving mainly the mucosa (Fig. 11). In larvae mainly primary folds were seen. Villi were lacking in all parts of the intestine. The epithelium consisted mainly of tall, microvillous columnar cells and PAS-positive goblet cells. Lymphocytes and rodlet cells were occasionally observed in the epithelial layer, in addition to enteroendocrine cells.

In the juveniles and adults, areas with lower, more basophilic epithelial cells of a less regular shape were evenly distributed in all parts of the mucosa. These areas were associated with small epithelial folds that in serial sections appeared to represent shallow, funnel-shaped, crypt-like structures. Mitotic figures were present in these structures, while goblet cells were lacking in their bottom part.

Major morphological differences were not observed between the 3 regions sampled in juvenile and adult proximal intestine. In the distal intestine, however, primary mucosal folds were lower and goblet cells more numerous, and the columnar epithelial cells contained PAS-positive granules in the apical cytoplasm. Ultra- 


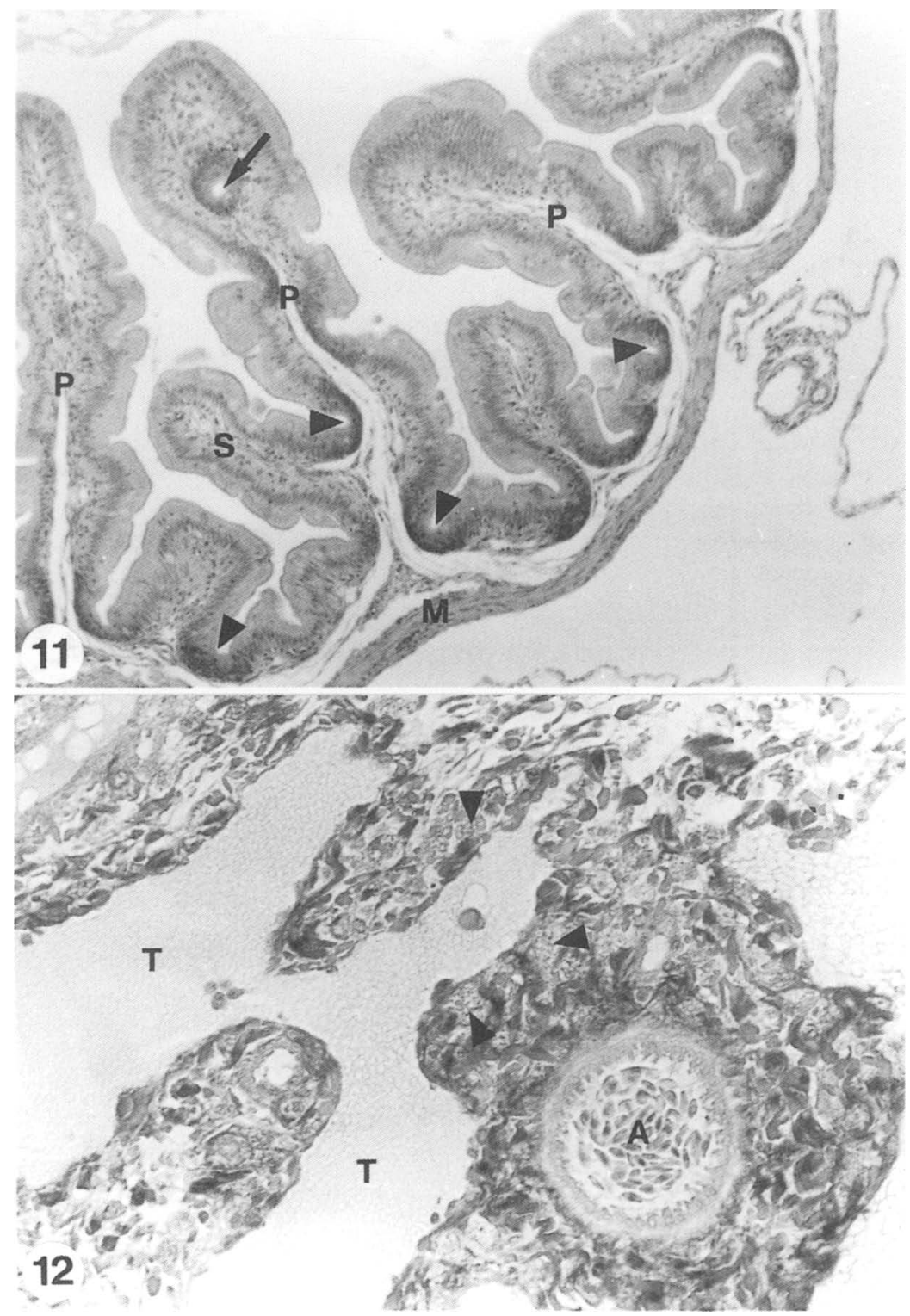

Figure 11. Light micrograph of $\mathrm{HE}$ stained juvenile intestine showing primary $(\mathrm{P})$ and secondary $(\mathrm{S})$ folds and tunica muscularis (M). Small, epithelial folds (arrowheads). Transverse section (arrow) showing the funnelshaped aspect of these structures. $\times 286$.

Figure 12. Light micrograph of MSB-stained adult intestine showing vessels in the collagen-rich connective tissue at the base of a primary fold. Wide, irregularly shaped, thin-walled vessels (T) can be discerned, along with an arteriole (A). EGCs (arrowheads) are observed perivascularly. $\times 458$. 


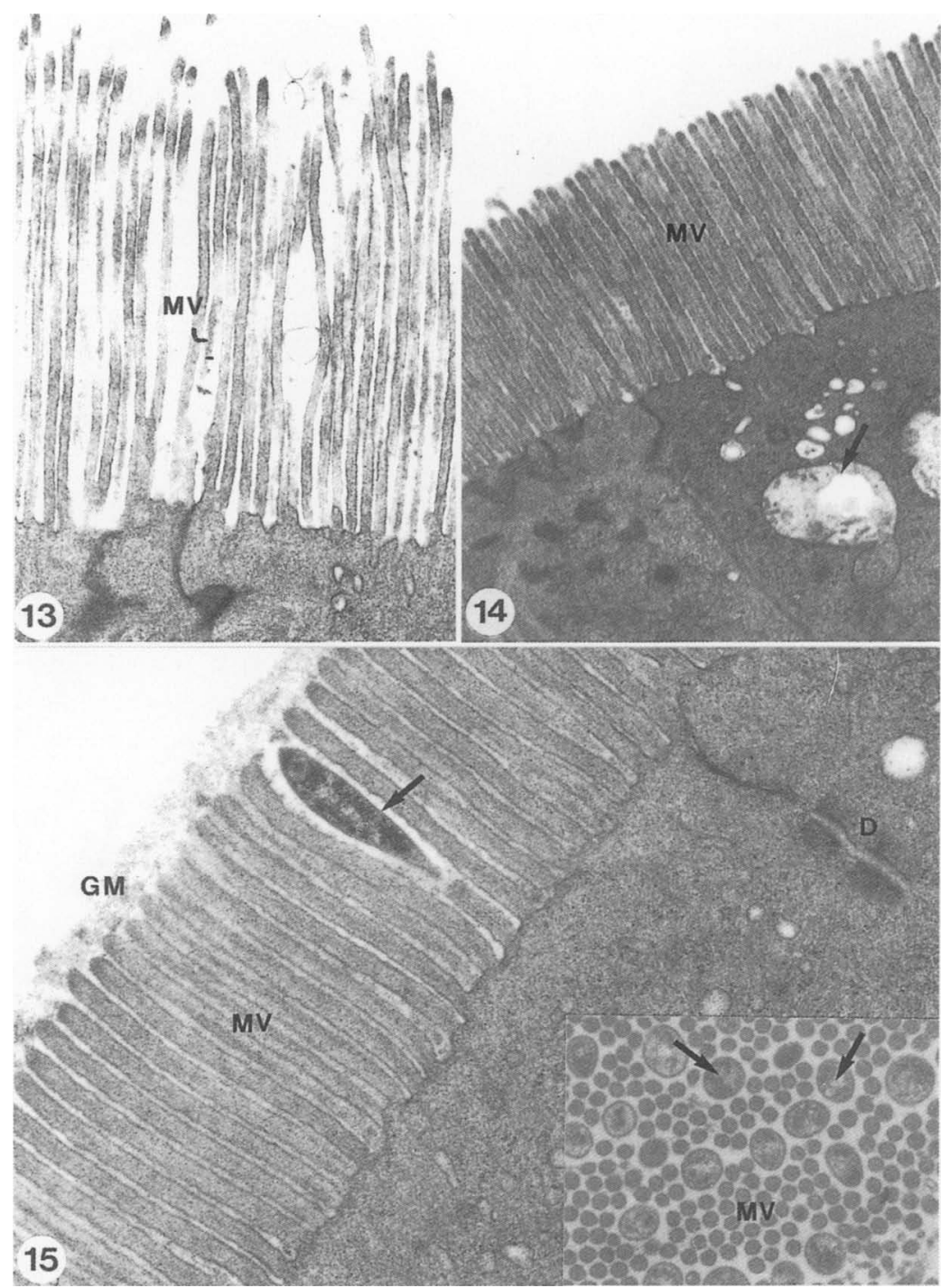

Figure 13. Ultramicrograph of cranial proximal intestine showing the apical cytoplasm and $4 \mu \mathrm{m}$ long microvilli (MV) of the columnar epithelial cells. $\times 20000$.

Figure 14. Ultramicrograph of middle proximal intestine showing the apical cytoplasm and $2.5 \mu \mathrm{m}$ long microvilli (MV) of the columnar epithelial cells. Mitochondria (arrow) $\times 16000$.

Figure 15. Ultramicrograph of distal intestine showing the apical cytoplasm and microvilli (MV) of the columnar epithelial cells. The $1.5 \mu \mathrm{m}$ long microvilli are covered by mucus (GM) from goblet cells. A bacterium (arrow) is seen oriented in parallel with the microvilli. Desmosome (D). $\times 30000$. Inset: Transverse section of brush border showing microvilli and bacteria (arrows) $\times 30000$. 
structurally, varying numbers of osmiophilic droplets were observed in the cytoplasm of the epithelial cells in the proximal intestine, but more rarely in the distal intestine. Invaginations of the intermicrovillous apical plasma membrane were prominent in the distal intestine, but were only occasionally observed in the proximal part. A well-developed tubulovesicular network was present in the apical cytoplasm in the distal intestine, and in some sections contacts with plasma-membrane invaginations were seen.

The microvilli of the epithelial cells had a constant diameter, approximately $0.1 \mu \mathrm{m}$, and were tallest in the first part of the proximal intestine and gradually decreased distally (Figs. 13-15). Numerous rod-shaped bacteria with a granular cytoplasm and a distinct cell wall were observed between the microvilli in the distal intestine (Fig. 15).

Scattered smooth muscle cells were observed in the loose subepithelial connective tissue, but an organized muscularis mucosae was lacking. The layer of dense, collagen-rich connective tissue, containing thin-walled vessels and EGCs, continued in the intestine, and large vessels were located at the base of large primary mucosal folds (Fig. 12). A close association of EGCs with the endothelium of the irregular, thin-walled vessels was observed. In one-dayold larvae, submucosal connective tissue was sparse and mainly found at the base of the larger mucosal folds, and definite EGCs were not observed.

The tunica muscularis consisted of an inner circular and an outer longitudinal layer of smooth muscle. In histological sections of adult intestine, the inner circular layer was markedly thicker than the outer longitudinal, sometimes twice as thick. In the juveniles, they were each 3-5 cell-layers thick, while in the larvae they only exhibited 1-3 cell-layers.

\section{Discussion}

Several new light- and electron-microscopic observations were made in the present study of the alimentary canal in common wolffish. The discussion will here concentrate on functional aspects of these findings and comparisons will be drawn with wild-caught wolffish and other relevant fish species. Morphological differences due to dietary factors may exist between wild-caught and farmed wolffish. Such differences may, however, be difficult to appreciate, since only a few, limited studies have been published dealing with wild-caught wolffish, and the information on juveniles in particular is very scarce.

\section{Oesophagus}

The occurrence of a simple columnar epithelium in the oesophagus has been reported in several other marine species (Al-Hussaini 1946, Cataldi et al. 1987, Grau et al. 1992). Different functions have been suggested for the two epithelia, with mucous production for the dominating, squamous stratified epithelium, and an osmoregulatory function, involved in desalination of ingested seawater, for the microvillous, simple columnar epithelium (Yamamoto 1978, Meister et al. 1983, Cataldi et al. 1988). The association of the simple columnar epithelium with thin-walled, wide capillaries, the low amounts of sodium and chloride ions, and the high $\mathrm{pH}$ of wolffish stomach fluids (Bray 1987), all support the suggestion of an osmoregulatory function (Yamamoto 1978, Meister et al. 1983, Cataldi et al. 1988). Capillaries with a similar morphology, such as the fenestrated capillaries in the rete mirabile of swim bladder (Stray-Pedersen \& Nicolaysen 1975, Morrison 1987) and the mammalian gastrointestinal tract (Simionescu \& Simionescu 1988), are known to have a large transport capacity. 


\section{Stomach}

The acinar gastric glands seen in common wolffish, contrast with the long, tubular glands found in most other teleost species (Reifel \& Travill 1978). This, along with other findings, have lead to the claim that stomach function is reduced in wolffish (Bray 1987). Our ultrastructural studies did, however, not indicate any different function of the wolffish gastric glands compared with those of other teleost species, including freshwater (Noaillac-Depeyre \& Gas 1978, Garrido et al. 1993) and marine (Ling \& Tan 1975, Morrison 1987, Murray et al. 1994). Our results also show that the stomach was morphologically well differentiated in one-dayold larvae, which is consistent with the fact that larvae may start feeding immediately after hatching (Pavlov \& Novikov 1986). The distribution of acinar glands throughout the stomach is consistent with earlier studies on wild-caught wolffish (Haus 1897). The lower density in the pyloric part approaches the situation in other teleost species where glandular tissue is usually limited to the corpus (Noaillac-Depeyre \& Gas 1978, Reifel \& Travill 1978).

The mucoid granules of the neck cells in the present material were larger and fewer in number than those described in other teleost species (Dawes 1929, Al-Hussaini 1946, Noaillac-Depeyre \& Gas 1978, Murray et al. 1994). The observed difference between juveniles and adults could indicate a gradual increase or differentiation of neck cells with maturation. The collagen-rich connective tissue layer and thin-walled vessels in the submucosa will be discussed along with the similar structures of the intestine. This also applies to the EGCs.

\section{Intestine}

The wolffish intestine was short, but had an extensively folded mucosa, creating a large surface for digestion and absorption, a feature often found in highly specialized predators with a short intestine (Kapoor et al. 1975). In teleost species with simple, primary folds, regeneration of intestinal epithelium has generally been thought to take place at the base of folds. The situation in species with a more complex folding has not been clearly stated. We suggest that the present shallow, crypt-like structures, which are for the most part made up of poorly differentiated cells, are the site of intestinal epithelial proliferation in wolffish juveniles and adults. The dynamics of the wolffish intestinal epithelial-renewal are, however, clearly a target for future research.

Histochemical, ultrastructural and functional differences have been observed between proximal and distal intestine in several teleost species (Yamamoto 1966, Iwai \& Tanaka 1968). The present findings indicate that corresponding functional differences exist in common wolffish, with morphological characteristics of lipid absorption primarily observed in the proximal intestine. The PAS-positive granules demonstrated in the apical cytoplasm of epithelial cells in the distal intestine are consistent with pinocytotic vacuoles believed to be involved in protein absorption (Gauthier \& Landis 1972). The microvilli of teleost enterocytes are generally longer than those observed in the mammalian small intestine (Trier \& Rubin 1965), and the microvilli seen in the present wolffish were longer than those of several other teleost species (Iwai 1968, MacDonald 1987, Kuperman \& Kuzmina 1994). The observation of distally decreasing microvillous length agrees with findings both in teleosts (Odense \& Bishop 1966, Krementz \& Chapman 1975, Kjørsvik et al. 1991) and mammals (Weiss 1988).

It is likely that the bacteria that were associated with the microvilli of distal intestine are part of an indigenous intestinal microflora. Several studies have indicated an existence of a specialized intestinal microflora in fish (Lindsay \& Gooday 1985, Hansen et al. 1992), and a simi- 
lar intimate association as observed in the present distal intestine has been reported in cod (Odense \& Bishop 1966, Morrison 1987) and in mammals (Klaasen et al. 1992).

The lack of a distinct muscularis mucosae seems to be a general feature of the teleost alimentary canal (Harder 1975). The layer of dense, collagen-rich connective tissue observed immediately adjacent to the tunica muscularis is different from the stratum compactum of Salmonids, but is comparable to the findings in several other species, both freshwater (McVay \& Kaan 1940), and marine (Blake 1936, Murray et al. 1996). The significance of this structure is not clear, but it will definitely add strength to the gut wall, and may also create a skeleton for the network of thin-walled vessels, which were observed in both the gastric and intestinal submucosa of juveniles and adults in our study. These vessels seem to correspond to lymphatic vessels reported in the gastrointestinal tract of plaice (Pleuronectes platessa L.) (Wardle 1971), tilapia (Tilapia nilotica L.) (Osman \& Caceci 1991) and common wolffish (Weidenreich et al. 1933, Verighina 1974). There is, however, some controversy as to whether teleost fish possess a distinct lymphatic system, or if it is a system of secondary blood vessels (Vogel \& Claviez 1981, Steffensen et al. 1986).

The association of EGCs with the collagen-rich areas in juvenile and adult wolffish resembles that of other species lacking a distinct stratum compactum and stratum granulosum (Blake 1936, McVay \& Kaan 1940, Al-Hussaini 1946, Reifel \& Travill 1978). The perivascular distribution and the association with the thin-walled vessels may be consistent with the belief that the EGCs in fish are mast-cell analogues (Reite 1996). The failure to detect distinct EGCs in one-day-old wolffish larvae could indicate that these cells were not present in the gastrointestinal tract at this stage, or that they were not suf- ficiently differentiated to be easily detected by the histological methods employed.

The main purpose of the present study on wolfish alimentary canal was to provide a morphological basis for diagnostic work and research. Several observations need, however, further clarification and should be targets for further research. These include the process of proliferation and elimination of intestinal epithelial cells, as well as the function and morphology of the thin-walled vessels and their close association with the EGCs.

\section{Acknowledgements}

The authors would like to thank professor Erlend Moksness, Institute of Marine Research, Flødevigen Marine Research Station for providing the material for the study and the Histological laboratory, Department of Morphology, Genetics and Aquatic Biology, for technical assistance. Also we would like to thank senior technician Else Engeland for photomicrograph development and copying.

\section{References}

Al-Hussaini AH: The anatomy and histology of the alimentary tract of the bottom-feeder, Mulloides auriflamma (Forsk.). J. Morphology, 1946, 78, 121-153

Baeverfjord G, Krogdahl A: Development and regression of soybean meal induced enteritis in Atlantic salmon, Salmo salar L., distal intestine: a comparison with the intestines of fasted fish. J. Fish Diseases 1996, 19, 375-387

Blake IH: Studies on the comparative histology of the digestive tube of certain teleost fishes III. A bottom-feeding fish, the sea robin (Prionotus carolinus). J. Morphology 1936, 60, 77-102

Bray RA: A study of the helminth parasites of Anarhichas lupus (Perciformes: Anarhichadidae) in the North Atlantic. J. Fish Biology 1987, 31, 237264.

Carleton HM, Leach EH: Histological technique. 2. Oxford University Press, London, 1968.

Cataldi E, Cataudella S, Monaco G, Rossi A, Tancioni, $L$ : A Study of the histology and morphology of the digestive tract of the sea-bream, Sparus aurata. J. Fish Biology 1987, 135-145.

Cataldi E, Crosetti D, Conte G, D'Ovido D. Catau- 
della $S$ : Morphological changes in the oesophageal epithelium during adaptation to salinities in Oreochromis mossambicus, O. niloticus and their hybrid. J. Fish Biol. 1988, 32, 191-196.

Dawes B: The histology of the alimentary tract of the plaice (Pleuronectes platessa). Quarterly J. Microscopical Science (1929), 73, 243-274.

Garrido MVO, Torres MIN, Equisoain M A A: Histological, histochemical and ultrastructural analysis of the gastric mucosa in Oncorhynchus mykiss. Aquaculture 1993, 115, 121-132.

Gauthier GF, Landis SC: The relationship of ultrastructural and cytochemical features to absorptive activity in the goldfish intestine. Anatomical Record 1972, 172, 675-702.

Grau A, Crespo S, Sarasquete MC, Gonzalez de Canales $M L$ : The digestive tract of the amberjack Seriola dumerili, Risso: a light and electron microscopic study. Journal of Fish Biology 1992, 41, 287-303.

Hansen $G$, Ström E, Olafsen J: Effect of different holding regimens on the intestinal microflora of herring (Clupea harengus) larvae. Applied and Environmental Microbiol. 1992, 58, 461-470.

Harder $W$ : Anatomy of Fishes. 2. E. Schweizerbart'sche Verlagsbuchhandlung, Stuttgart, 1975.

Haus GA: Beitrage zur Anatomie und Histologie des Darmkanales bei Anarhichas lupus. (Comments on the anatomy and histology of the alimentary canal in Anarhichas lupus). Internationale Monatsschrift Für Anatomie und Physiologie 1897, 14, 42-51 + Tafel V.

Iwai T, Tanaka $M$ : The comparative study of the digestive tract of teleost larvae -IV. Absorption of fat by the gut of halfbeak larvae. Bull. Japanese Society of Scientific Fisheries 1968, 34, 871-875

Iwai T: Fine structure and absorption patterns of intestinal epithelial cells in rainbow trout alevins. Zeitschrift für Zellforschung 1968, 91, 366-379.

Jonsson $G$ : Contribution to the biology of catfish (Anarhichas lupus) at Iceland. Rit Fiskideild. 1982, 6, 3-26

Kapoor BG, Smit H, Verighina IA: The alimentary canal and digestion in teleosts. Advances in Marine Biology 1975, 13, 109-239

Kjørsvik E, van der Meeren T, Kryvi H, Arnfinnson J, Kvenseth $P G$ : Early development of the digestive tract of cod larvae, Gadus morhua L., during start-feeding and starvation. Journal of Fish Biology 1991, 38, 1-15.

Klaasen HLBM, Koopman JP, Poelma FGJ, Beynen $A C$ : Intestinal, segmented, filamentous bacteria.
FEMS Microbiology Reviews 1992, 88, 165-180.

Krementz $A B$, Chapman $G B$ : Ultrastructure of the posterior half of the intestine of the Channel catfish, Ictalurus punctatus. Journal of Morphology 1975, 145, 441-482.

Kuperman BI, Kuzmina $V V$ : The ultrastructure of the intestinal epithelium in fishes with different types of feeding. J. Fish Biology 1994, 44, 181-193.

Lindsay GJH, Gooday GW: Chitinolytic enzymes and the bacterial microflora in the digestive tract of cod, Gadus morhua. J. Fish Biology 1985, 26, 255-265.

Ling EA, Tan $C K$ : Fine structure of the gastric epithelium of the Coral fish, Chelmon rostratus Cuvier. Okajimas Folia Anatomica Japonica 1975, 51, 285-310.

MacDonald NL: An electron microscopic examination of the gastrointestinal epithelium in Dover sole, Solea solea (L.). J. Fish Biology 1987, 31, 27-36.

McVay JA, Kaan HW: The digestive tract of Carassius auratus. Biol. Bull. 1940, 78, 53-67.

Meister MF, Humbert W, Kirsch R, Vivien-Roels B: Structure and ultrastructure of the oesophagus in sea-water and fresh-water teleosts (Pisces). Zoomorphology 1983, 102, 33-51.

Moksness E: Growth rates of the common wolffish, Anarhichas lupus L., and spotted wolffish, A. minor Olafsen, in captivity. Aquaculture and Fisheries Management 1994, 25, 363-371.

Moksness E, Gj申sceter J, Reinert A, Fjallstein IS: Start-feeding and on-growing of wolffish ( $A n$ arhichas lupus) in the laboratory. Aquaculture 1989, 77, 221-228.

Morrison CM: Histology of the Atlantic cod, Gadus morhua: An atlas Part one. Digestive tract and associated organs. 1. Department of Fisheries and Ocean, Ottawa, 1987.

Murray $H$, Wright $G$, Goff $G$ : A comparative histological and histochemical study of the stomach from three species of pleuronectid, the Atlantic halibut, Hippoglossus hippoglossus, the yellowtail flounder, Pleuronectes ferruginea, and the winter flounder, Pleuronectes americanus. Can. J. Zool. 1994, 72, 1199-1210.

Murray H, Wright G, Goff $G$ : A comparative histological and histochemical study of the post-gastric alimentary canal from three species of pleuronectid, the Atlantic halibut, the yellowtail flounder and the winter flounder. J. Fish Biol. 1996, 48, 187-206.

Noaillac-Depeyre J, Gas N: Ultrastructural and cyto- 
chemical study of the gastric epithelium in a fresh water teleostean fish (Perca fluviatilis). Tissue \& Cell 1978, 10, 23-37.

Odense P, Bishop C: The ultrastructure of the epithelial border of the ileum, pyloric caeca, and rectum of the cod, Gadus morhua. J. Fisheries Res. Board Can. 1966, 23, 1841-1843.

Osman AHK, Caceci T: Histology of the stomach of Tilapia nilotica (Linnaeus, 1758) from the river Nile. Journal of Fish Biology 1991, 38, 211-223.

Pavlov DA, Moksness E: Production and quality of eggs obtained from wolffish (Anarhichas lupus L.) reared in captivity. Aquaculture 1994 A,122, 295-312.

Pavlov DA, Moksness E: Reproductive biology, early ontogeny and effect of temperature on development in Wolffish: comparison with salmon. Aquaculture International 1994 B, 2, 133-153.

Pavlov DA, Novikov GG: On the development of biotechnology for rearing of white sea wolffish, $A n$ arhichas lupus marisalbi. I. Experience on obtaining mature sex products, incubation of eggs and rearing of the young fish. J. Ichthyology 1986, 26, 95-106.

Reifel $C W$, Travill AA: Structure and carbohydrate histochemistry of the stomach in eight species of Teleosts. J. Morphology 1978, 158, 155-168.

Reite $O B$ : The mast cell nature of granule cells in the digestive tract of the pike, Esox lucius: similarity to mammalian mucosal mast cells and globule leucocytes. Fish \& Shellfish Immunology 1996, 6, 363-369.

Simionescu N, Simionescu M: The cardiovascular system. In: Weiss, L., (ed.): Cell and tissue biology. A textbook of histology. Urban \& Schwarzenberg, Inc., Baltimore 1988, 355-400.

Steffensen JF, Lomholt JP, Vogel WOP: In vivo observations on a specialized microvasculature, the primary and secondary vessels in fishes. Acta Zoologica 1986, 67, 193-200.
Stray-Pedersen S, Nicolaysen A: Qualitative and quantitative studies of the capillary structure in the rete mirabile of the eel, Anguilla vulgaris L. Acta physiol. Scand. 1975, 94, 339-357.

Trier J, Rubin C: Electron microscopy of the small intestine: a review. Gastroenterology 1965, 49, 574-603.

Verighina IA: The structure of the alimentary tract in some of the northern Blennioidei. I. The alimentary tract of the Atlantic wolffish (Anarhichas lupus). J. Ichthyology 1974, 14, 954-959.

Vogel WO, Claviez M: Vascular specialization in fish, but no evidence for lymphatics. Zeitschrift für Naturforschung 1981, 36, 490-492.

Wardle CS: New observations on the lymph system of the plaice Pleuronectes platessa and other teleosts. J. Marine Biol. Assoc. United Kingdom 1971, 51, 977-990.

Weidenreich F, Baum H, Trautmann A: Lymphgefässystem (Lymphoties). In: Bolk L, Göppert E, Kallius E, Lubosch W, (eds.): Handbuch der vergleichenden Anatomie der Wirbeltiere. VI Band. (Handbook on Comporative anatomy of vertebrates. vol.VI). Urban \& Schwarzenberg, Berlin 1933,745-854.

Weiss L, Ed: Cell and tissue biology: A textbook of histology. Urban \& Schwarzenberg, Inc., Baltimore 1988.

Yamamoto M, Hirano T: Morphological changes in the esophageal epithelium of the eel, Anguilla japonica, during adaptation to seawater. Cell and Tissue Research 1978, 192, 25-38.

Yamamoto T: An electron microscope study of the columnar epithelial cell in the intestine of fresh water teleosts: goldfish (Carassius auratus) and rainbow trout (Salmo irideus). Zeitschrift für Zellforschung und Mikroskopische Anatomie 1966, 72, 66-87.

(Received June 25, 1999; accepted April 30, 2000).

Reprints may be obtained from H. Hellberg, National Veterinary Institute-Bergen, P.O. Box 40 Minde, N-5826 Bergen, Norway. E-mail: hege.hellberg@vetinst.no, tel: (+47) 553638 19, fax: (+47) 55280954. 